\title{
АВІАЧИЙН ДВИГУНИ
}

УДК 629.7 .036

М.С. Кулик, А.В.Тарасенко

\section{АВТОМАТИЗОВАНІ СИСТЕМИ СУЩРОВОДУ ЕКСПЛУАТАПӤ АВІАЦЙНИХ ДВИГУНІВ}

\begin{abstract}
Розглянуто питання про дочільність створення автоматизованих систем супроводу експлуатачії авіатійних двигунів на рівнях експлуатачійного підприємства $i$ державного регулювання. Затропоновапо основні приниипи формування інформачійних потоків для вирішування проблем підвищення надійності і ефективності експлуатачї авіачійних двигунів.
\end{abstract}

Проблеми регулювання безпечної і ефективної діяльності авіаційного транспорту потребують своєчасного вирішення комплексу питань, зокрема, обліку наявності і планування необхідного парку авіаційної техніки, контролю їі технічного стану та прогнозування надійної і безвідмовної роботи під час польоту, а також рішення завдань підвищення економічних показників авіаційних перевезень.

Авіаційні двигуни $є$ однією з основних функціональних систем, якій належить провідне місце в ціновому балансі вартості повітряного судна і в структурі складових безпеки польотів, і тому вони потребують особливої уваги при вирішенні питань організації безпечної $\mathrm{i}$ ефективної діяльності повітряного транспорту. У зв'язку з цим виникає необхідність розробки та впровадження в практичну діяльність автоматизованих систем супроводу експлуатації авіаційних двигунів [1].

Слід відзначити, що вирішення означених питань ка рівні експлуатаційного підприємства (авіаційної компанії) і на державному рівні потребують розв'язання питань різного характеру. Це можна прослідкувати на прикладі вирішення питань забезпечення надійності авіаційної техніки.

Як відомо, основною умовою забезпечення надійності є суворе дотримання загально відомого правила, названого «тріадою надійності». Надійність закладається при проектуванні, забезпечується під час виробництва і підтримується в експлуатації [2].

Без обов'язкового виконання всіх трьох частин цього правила неможливо створити високонадійну техніку, а також компенсувати недоробки попереднього етапу наступним. Якщо при проектуванні не повністю вирішені питання розробки двигуна з заданим рівнем надійності і не закладені конструктивні рішення, що забезпенують безвідмовне функціонування всіх його деталей і систем, то ці недоліки не можна усунути в процесі виробництва, i ïх наслідки призведуть до низької надійності даного типу двигунів в експлуатації. В експлуатації, в свою чергу, повинні в повному обсязі виконуватись визначені нормативно-технічною і експлуатаційною документацією всі роботи по контролю технічного стану і технічному обслуговуванню.

Таким чином, можна визнати, що для забезпечення високого рівня надійності авіаційних двигунів необхідно вирішити такі питання:

а) на рівні експлуатаційного підприємства необхідно організувати і забезпечити поточний контроль технічного стану кожного авіаційного двигуна та виконання всіх робіт по технічному обслуговуванню, визначених технічною і експлуатаційною документацією;

б) на державному рівні необхідно забезпечити суворий контроль відповідності діючим вимогам всіх процесів розробки і виготовлення авіаційних двигунів і введення ї в експлуатаци, а також контроль відповідності процесів експлуатації і технічного обслуговування вимогам чинної нормативно-технічної і експлуатаційної документації та розпорядженням адміністративно-наглядових органів. 
На рівні експлуатаційного підприємства необхідно здійснювати безперервний контроль за динамікою змін всіх показників експлуатації і параметрів роботи кожного окремого двигуна, проводити поточний аналіз його технічного стану з метою попередження відмови в польоті. Обов' язково вести облік часу роботи кожного двигуна з урахуванням окремо тривалості роботи в польоті, на землі, на окремих робочих режимах, а також кількості польотних циклів, шо необхідно для призначення проведення тих або інших робіт по технічному обслуговуванню, а також для обчислення виробітку встановлених ресурсів і календарних термінів роботи.

Для забезпечення інтересів контролю і регулювання процесу експлуатації авіаційних двигунів на державному рівні зазначені вище складові можуть бути зайвими. Рішення питань на цьому рівні більше пов'язано 3 оцінкою ресурсних можливостей загального парку двигунів конкретного типу, оцінкою іх надійності і плануванням ремонту та оновлення парку і забезпечення запасними частинами.

Таким чином, виникає необхідність в організації систем супроводу експлуатації авіаційних двигунів окремо для рішення питань на рівні експлуатаційного авіапідприємства (система першого рівня) і на державному рівні (система другого рівня).

Прикладом автоматизованої системи першого рівня може бути система діагностування двигунів НК-8-2У на літаках ТУ-154 («Контроль-8-2У»), розроблена в КМУЦА і введена в експлуатацію в 1988 році в Бориспольскому авіапідприємстві [3], або система супроводу двигунів ПС-90А [4].

Враховуючи, що в Україні однотипну авіаційну техніку експлуатує значна кількість авіакомпаній, і не кожна 3 них має можливості мати власну автоматизовану систему супроводу авіаційних двигунів, виникає необхідність створення автоматизованих систем першого рівня для забезпечення супроводу авіаційних двигунів одночасно в декількох авіакомпаніях.

Організаційна структура (функціональна схема) такої системи показана на рис. 1.

Структура таккої системи передббачує створення єдиного аналітичного цектру, який має надійний електронний зв'язок з авіапідприємствами, що експлуатують конкретний означений тип авіаційних двигунів.

В кожному експлуатаційному авіапідприємстві у виробничо-диспетчерському відділі збирається вся інформація, яка необхідна для оцінки технічного стану кожного екземпляра приписного парку авіаційних двигунів та для проведення аналізу і прийняття необхідних рішень по забезпеченню процесу експлуатації.

До основних видів інформації можна вілнести наступні:

- параметри робочого процесу двигунів і атмосферні умови, які зареєстровані під час польоту членами екіпажу і засобами об'єктивного контролю;

- параметри, зареєстровані під час наземних гонок і випробувань;

- дані, одержані при використанні візуально-оптичних та інструментальних методів контролю при технічному обслуговуванні;

- результати спектрального аналізу масла;

- результати віброконтролю та вібродіагностики;

- дані про виконання регламентних робіт при технічному обслуговуванні;

- дані про виконання робіт за діючими бюлетенями;

- дані про напрацювання двигунів під час польотів і на землі в цілому за період роботи і на окремих режимах;

- дані про кількість виконаних польотів;

- дані про кількість відмов та неполадок двигунів і їх агрегатів, що сталися в процесі експлуатації;

- формулярні дані кожного екземпляра приписного парку авіаційних двигунів тощо. 


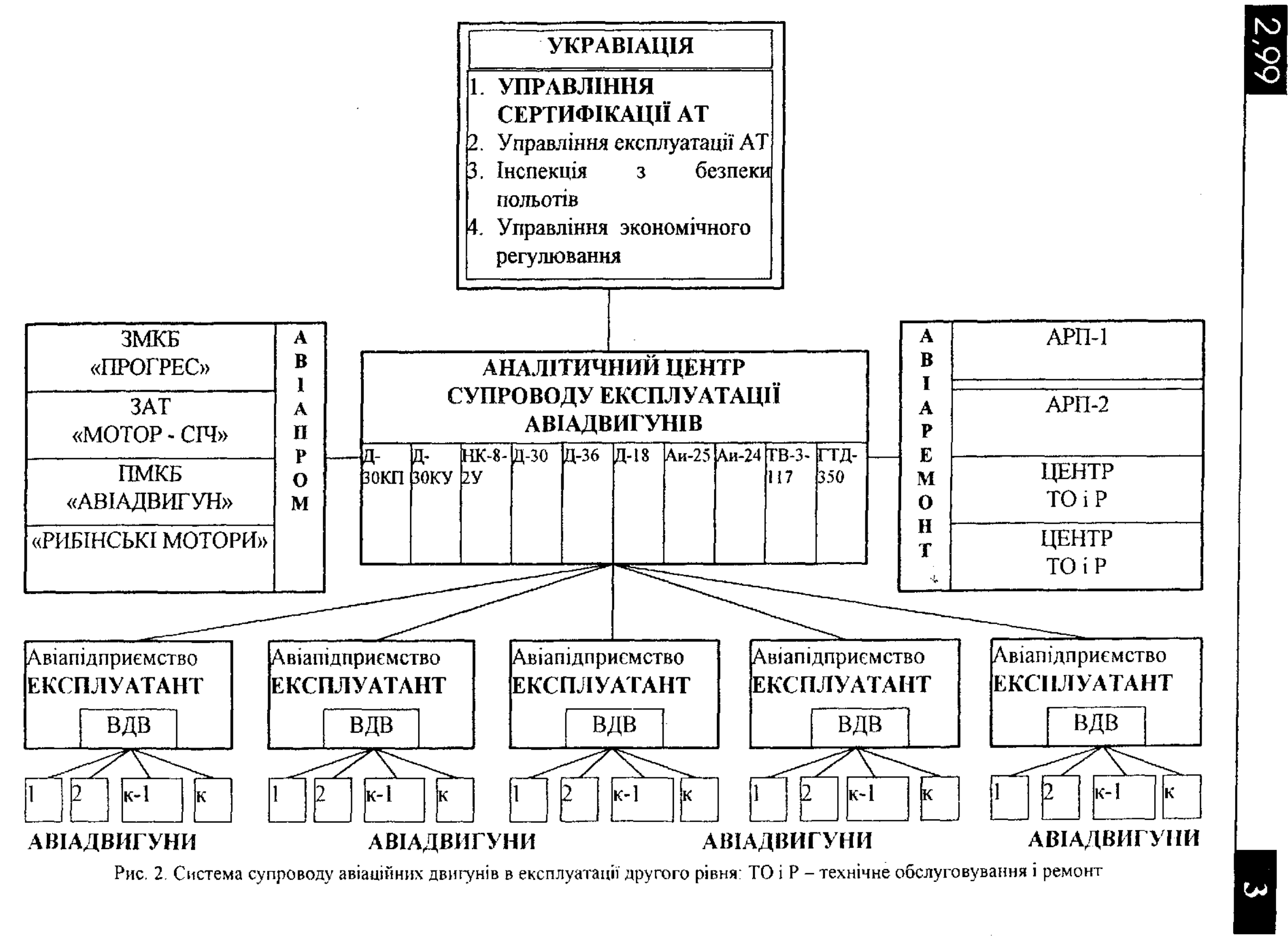




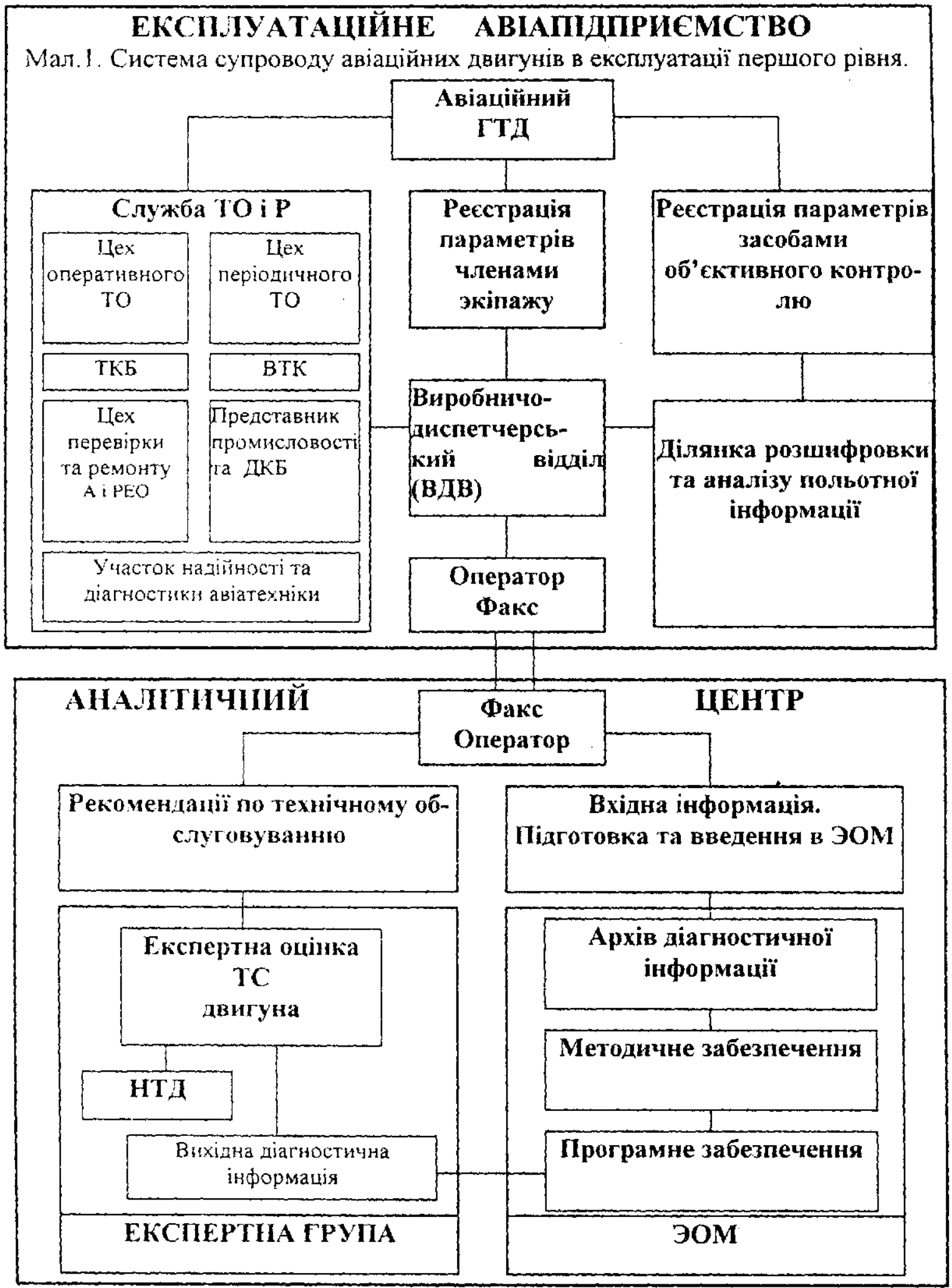

Pис.]. Система сутроводу авіанійних двигудів в експлуттації першото рівня ТО - технічне обстуговувапин: ДКБ - достідно-констукторсыке бюро; ВТК - вілділ технінного контролю

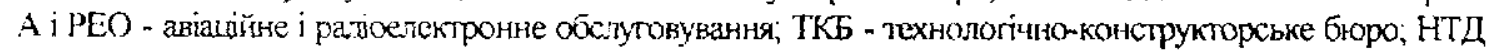
науково-текнітна документація; ТС - технічний стан 
Ця інформація в установленій формі і з визначеною періодичністю з допомогою електронних засобів зв'язку передається з експлуатаційного підприємства в регіональний аналітичний центр.

Аналітичний центр являє собою класичну автоматизовану систему, створену на базі електронно-обчислювальної техніки, яка складається з апаратурного, інформаційного, методичного та програмного забезпечення, а також групи фахівців-експертів.

Інформація, що надійшла від експлуатаційного підприемства, проходить вхідний контроль і підготовку, після чого вводиться в ЕОМ. Таким чином формується архів необхідноі інформації.

В залежності від поставлених при створенні автоматизованої системи завдань розробляються методики і програми обробки інформації. Так, наприклад, при вирішенні питання оцінки технічного стану авіаційного двигуна з архіву вибирається тільки та інформація, яка накопичена за весь контрольований період експлуатації даного конкретного двигуна $\mathrm{j}$ необхідна для проведення обрахункових операцій згідно з розробленими і затвердженими в установленому порядку методиками оцінки технічного стану авіаційних двигунів. В кінцевому результаті на виході отримусться діагностична інформація, яка поступає в експертну групу

В експертній групі спеціально підготовлені фахівці аналізують отриману діагностичну інформацію, приймають відповідні висновки i формулюють рекомендації щодо подальшої експлуатації даного двигуна.

Висновки про технічний стан даного авіаційного двигуна і рекомендації по технічному обслуговуванню 3 допомогою електронних засобів зв'язку передаються 3 аналітичного центру в експлуатаційне підприємство. Планово-виробничий відділ підприємства контролює виконання рекомендованих робіт по технічному обслуговуванню конкретного авіаційного двигуна i після їх завершення передає в аналітичний центр підтвердження про виконані вказівки. Ця інформація вводиться в архів в ЕОМ для використання при наступних операціях по аналізу гехнінного стану даного авіаційного двигуна.

Аналогічні процедури виконуються і при рішенні інших завдань, поставлених перед автоматизованою системою першого рівня.

Організаційна структура автоматизованої системи супроводу експлуатації авіаційних двигунів для рішення питань на державному рівні (система другого рівня) показана на рис. 2 .

Аналогічно системі першого рівня ця система також повинна мати свій аналітичний центр, який за допомогою електронних засобів зв'язку повинен бути з'єднаний з усіма суб'єктами, тобто організаціями і підприємствами, які забезпечують надійність авіаційних двигунів і несуть свою частку відповідальності за їх безвідмовну роботу при виконанні польотів. Такими суб'єктами виступають:

- державна авіаційна адміністрація України (Укравіація);

- організації-розробники авіаційних двигунів (за типами авіаційних двигунів);

- заводи-виробники авіаційних двигунів (за типами авіаційних двигунів);

- авіаційні ремонтні підприємства і центри технічного обслуговування і ремонту (за типами авіаційних двигунів);

- авіаційні експлуатаційні підприємства (за типами авіаційних двигунів); 
- науково-дослідні організації, які здійснюють розробку і впровадження прогресивних технологій і конструктивних рішень в процеси розробки, виробництва та експлуатації авіаційних двигунів.

Інформаційна база аналітичного центру автоматизованої системи другого рівня повинна бути створена таким чином, щоб задовольняти рішення питань за потребами кожного суб'єкта. Методичне забезпечення цієї системи повинно також розроблюватись з урахуванням інтересів кожного суб'єкта.

В зв'язку з цим першочерговим і надзвичайно важливим $є$ розробка технічного завдання і технічних умов для створення такої системи, погоджених з усіма зацікавленими суб'ектами.

Найбільш доцільно таку систему створити при Укравіації, яка $€$ державним органом регулювання всіх процесів по забезпеченню безпечної і ефективної експлуатації авіаційної техніки. Автоматизована система супроводу експлуатації авіаційних двигунів другого рівня може стати сучасним ефективним і необхідним інструментом для досягнення поставлених завдань по забезпеченню безпеки польотів і підвищенню економјчних показників транспортної роботи цивільної авіації України.

\section{Список літератури}

1. Тарасенко A.B. Особливості експлуатації авіаційних газотурбінних двигунів в умовах комерційної діяльності авіапідприємств// Вісник Київського міжнародного університету цивільної авіації.- К.: КМУЦА. - 1998. - № 1, - С.99-101.

2. Косточкин В.В.Надежность авиационных двигателей и силовых установок.- М.: Машиностроение, 1976. - 247 с.

3. Лозичкий Л.П., Авдошко М.Д., Тарасенко А.В. Автоматизированная система диагностирования ГТД «Контроль-8-2У». - К.: КИИГА, 1986, - $131 \mathrm{c}$.

4. Лозичкий JI.П., Тарасенко А.В. Разработка автоматизированной системы управления техническим состоянием двигателей ПС-90A// Обеспечение надежности авиационных двигателей в эксплуатации:Сб.науч.тр.- К.: КИИГА, 1993.- С. 10-20.

Стаття надійшла до редакції 30 вересня 1999 року. 